\title{
Design Wind Speed Estimation for Long Span Bridges in Korean Southern and Western Coasts
}

\author{
Dooyong Cho* \\ Department of Technology Education, Chungnam National University, Daejeon, Korea \\ Received 03 March 2019; received in revised form 25 October 2019; accepted 03 January 2020 \\ DOI: https://doi.org/10.46604/ijeti.2020.3545
}

\begin{abstract}
Recently, many long-span cable supported bridges, including the cable stayed bridges and the suspension bridges, have already been constructed or are planned for construction. Because the meteorological values used to estimate the wind load for designing the long-span bridges were based on data from the 1960s through 1995 in Korea, it is necessary to reconsider the proper design wind load for long-span bridges. In this paper, the research area is confined to the southern and western coasts of Korea where many long-span bridges have been built. The method of moment and the least-squares method are used to estimate the expected wind speeds of a 100-year return period for girder bridges; Gumbel's distribution is used to estimate the expected wind speeds of a 200 -year return period for long-span bridges. As the return period wind speed on the land surface is revised because of recent high-speed velocity, the revised return period wind speed is increased by $17 \%$. The compatibility of return period wind speed is also evaluated using the RMS (root mean square) error method. This paper concludes that the least-squares method is more compatible than the method of moment for the case of the southern and western coasts of Korea.
\end{abstract}

Keywords: basic wind speed, return period wind speed, least-squares method, RMS error method

\section{Introduction}

Recently, many long-span cable supported bridges, including the Incheon, Geoga and Lee Sun-Shin Bridge, with cable stayed bridge and suspension bridge types, have either been completed recently or are being built in Korea. In addition, the construction of National Highway Route 77 and a large-scale connecting bridge project are underway. When planning to construct such a marine long-span bridge, it is generally necessary to design the static wind load of the bridge; when doing so, determining the basic wind speed in the target area is a fundamental issue.

While the basic wind speed presented by the Korean Highway Bridge Design Code [1] has different values depending on the region and the installation year of weather stations, regional annual maximum wind records from 1951 to 1995 are approximated by the extreme value distribution (Gumbel's distribution) and estimated as the expected wind speeds of a 100 -year return period. This is generally applicable to a medium-small bridge less than $200 \mathrm{~m}$ in length, but not to a marine long-span bridge.

For these reasons, the Design Guidelines for Steel Cable-Supported Bridge [2] estimates the basic wind speed adequate for a long-span bridge based on the expected wind speeds of a 200-year return period. However, due to a lack of guidelines regarding the marine long-span bridges that were constructed before the issuance of the Design Guidelines for Steel Cable-Supported Bridge, there is a need for further studies [3]. In addition, the frequent occurrence of global warming-induced regional typhoons such as Kompasu, with instantaneous maximum wind speeds over $40-60 \mathrm{~m} / \mathrm{s}$, calls for constant review of the wind resistance of long-span bridges in the southern and western coasts, the main paths of such typhoons.

* Corresponding author. E-mail address: dooyongcho@cnu.ac.kr

Tel.: +82-41-8215693; Fax: +82-41-8253556 
Therefore, Kim and Ha [4] calculated the expected wind speeds of a 200-year return period that are applicable to wind-resistance design for the long-span bridges in the southern and western coasts using Gumbel's method of moments and the least-squares method, based on the measured wind data from local stations in the last 40 years. Additionally, many researchers have conducted investigations of the statistical characteristics of the wind speed in specific areas such as Palermo (Italy), La Ventosa (Mexico), UAE, North Dakota (United States), Kerman (Iran), Turkey and Santiago Island (Cape Verde), respectively [5-12]. Batts and Simiu [13] also employed the Hazen Plot to determine the eligibility of our calculations as well as revising the expected wind speeds by taking into account the extreme surface winds in coastal areas. In this study, we reviewed and compared the statistical characteristics of wind speeds presented in previous research, the Korean Highway Bridge Design Code, and those applied to actual long-span bridge design.

\section{Procedure of Analysis for Basic Wind Speed}

The procedures of analysis for basic wind speed presented by the Current Highway Bridge Design Code are estimated through the process shown in Fig. 1. Since analysis procedures for land bridge design are not suitable for marine long-span bridges, several adjustments were made based on the meteorological data for the past 40 years. First, the 100 -year return period presented by the Design Guidelines for Steel Cable-Supported Bridge is re-estimated as a 200-year return period. After the evaluation of suitability, the method of moment calculated via the extreme analysis method is replaced by employing the least-squares method. Finally, a design wind speed suitable for marine long-span bridges in the southern and western coasts is calculated by revising land wind speed to marine wind speeds of coastal regions under extreme conditions. The details of each process are as follows:

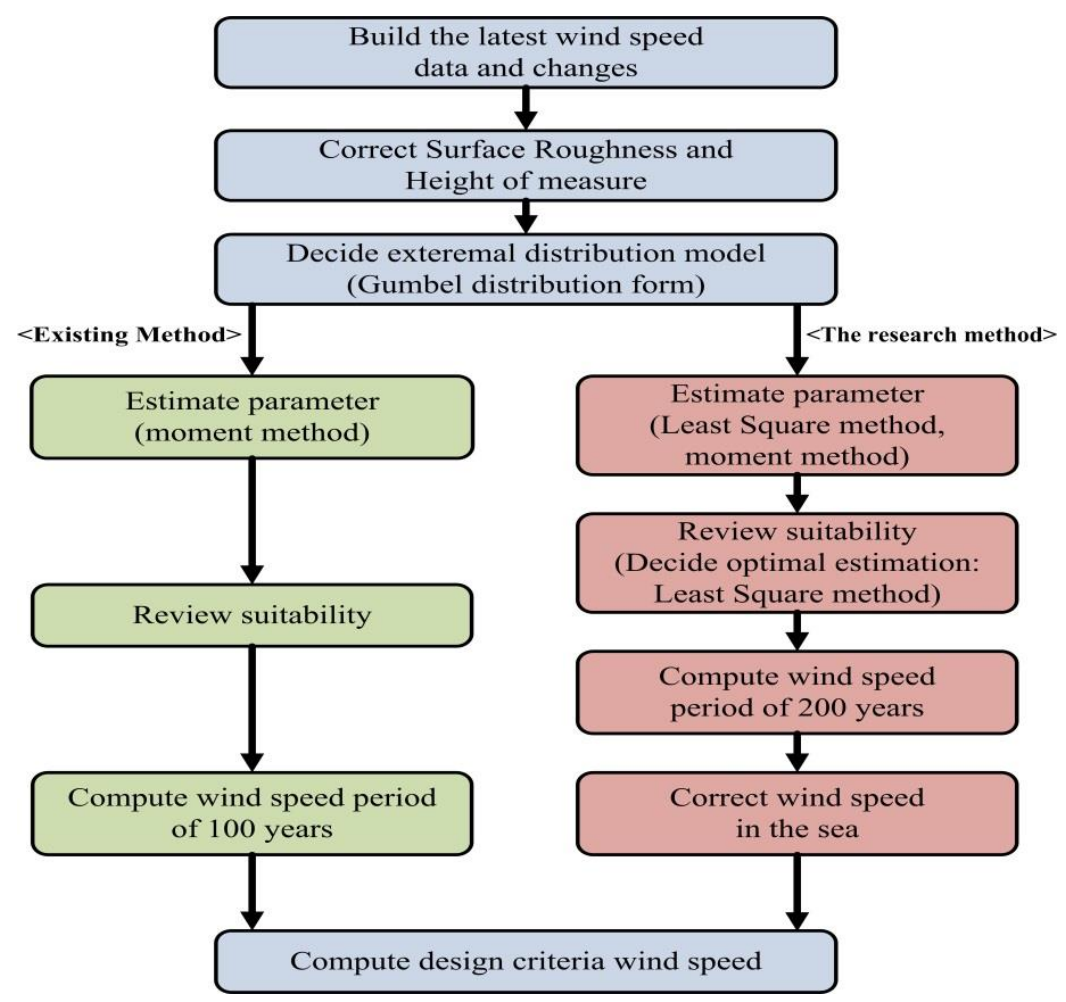

Fig. 1 Procedure of basic speed estimation

\subsection{Revision of observed data}

The Highway Bridge Design Code advises using the basic wind speed (V10) of 10 minutes of average wind speed over $10 \mathrm{~m}$ on the ground in an open area (roughness classification). Since the installation height of anemometers and the conditions around the weather stations are not constant, the comparison of records of each local weather station (annual maximum wind speed) would be unreliable. Therefore, comparable data should be presented that has the same conditions [4]. 
In case of relocated observatories or changed anemometer heights, necessary revisions are made with reference to the annual weather report of the Korean Meteorological Administration [14]. Wind speed is also revised by considering the effective height from the surface given by the following Eq. (1) in the region where a weather station is located on a hillside or in a mountainous area (Inchon, Kunsan, Mokpo, Yeosu and Tongyeong, Busan in Korea). Height variations of the wind observation stations are shown in Table 1. In Table 1, the number outside the parentheses is the year that the changes took place, and the number inside the parentheses is the height of sea level and anemometer of that year.

$$
Z_{e}=\left(H_{a}-\overline{H_{a}}\right)-\left(\bar{H}-\frac{Z_{0}}{k}\right)(m)
$$

where $\mathrm{Z}_{\mathrm{e}}$ is the effective height $(\mathrm{m})$ from the surface; Ha is the height of sea level (m) at the point; $\overline{H_{a}}$ is the average height of sea level; $\bar{H}$ is the average height of the building $(\mathrm{m}) ; \mathrm{Z}_{0}$ is roughness length around the region $(\mathrm{m})$, and $\mathrm{k}$ is the Karman constant $(\fallingdotseq 0.4)$. Revision of about wind speed is performed with the following steps.

1. Roughness of the surface is determined by referring to the study (Table.1).

Table 1 Height and surface roughness of observatory in the southern and western coasts

\begin{tabular}{|c|c|c|}
\hline Observatory & Surface Roughness & $\begin{array}{c}\text { Year of change } \\
\text { (elevation of Observatory/ } \\
\text { Height of anemometer) } \\
\text { (m) }\end{array}$ \\
\hline Soesan & III & $\begin{array}{l}71(19.7 / 12.5) 81(19.7 / 11.8) \\
98(25.9 / 14.0) 00(25.2 / 20.2)\end{array}$ \\
\hline Incheon & III & $\begin{array}{c}71(68.9 / 14.0) 85(68.9 / 11.0) \\
00(68.9 / 14.0) 05(54.6 / 11)\end{array}$ \\
\hline Gunsan & III & $\begin{array}{l}71(26.3 / 14.5) 00(25.6 / 18.0) \\
03(26.9 / 15.3) 04(26.9 / 18.0)\end{array}$ \\
\hline Yeosu & III & $71(67.0 / 10.5) 98(66.1 / 20.8)$ \\
\hline Tong-Yeong & III & $\begin{array}{c}71(32.2 / 14.9) 81(32.2 / 11.5) \\
98(30.8 / 15.2)\end{array}$ \\
\hline Jeju & III & $\begin{array}{c}71(22.0 / 10.5) 85(22.0 / 11.5) \\
87(22.0 / 12.3) 98(20.0 / 14.4) \\
04(19.9 / 12.3)\end{array}$ \\
\hline Mokpo & III & $71(53.4 / 15.8) 98(37.9 / 15.5)$ \\
\hline Ulsan & III & $\begin{array}{c}71(31.5 / 10.8) 98(34.7 / 16.4) \\
00(34.6 / 12.2)\end{array}$ \\
\hline Busan & IV & $71(69.2 / 17.8)$ \\
\hline Seogwipo & II & $\begin{array}{c}71(51.9 / 8.9) 81(51.9 / 9.2) \\
85(51.9 / 10.0) 08(50.4 / 10.0)\end{array}$ \\
\hline
\end{tabular}

2. Using altitude distribution coefficient $\mathrm{K}_{Z}$ on the surface roughness classification of each point, the wind speed of Step 1 is converted to the gradient wind velocity $\mathrm{Z}_{\mathrm{G}}$. Altitude distribution coefficient $\mathrm{K}_{\mathrm{Z}}$ presented by the Highway Bridge Design Code is applied as following Eqs. (2)-(3). Here, $Z_{G}$ is the height where wind speed is constant regardless of surface roughness, $\alpha$ is the altitude distribution exponent, and $Z_{b}$ is the representative height of the terrain. $Z_{G}, Z_{b}$, and $\alpha$ depend on the surface roughness of the surrounding area in a temporary location, and those values are determined from Table 2.

3. Using the vertical direction-altitude distribution coefficients $\mathrm{K}_{\mathrm{Z}}$ from the determining model of extreme distribution II of Table 1, the height of the gradient wind speed from Step 2 is converted to wind speed of $10 \mathrm{~m}$ from the ground. 
Table 2 The $\alpha, Z_{\mathrm{G}}, \mathrm{Z}_{\mathrm{b}}$ by changing the surface roughness

\begin{tabular}{|c|c|c|c|c|c|}
\hline Classification of surface roughness & Surface Condition & $\alpha$ & $\mathrm{Z}_{\mathrm{G}}$ & $\mathrm{Z}_{\mathrm{b}}$ & $\mathrm{Z}_{0}$ \\
\hline I & Sea, Coast & 0.12 & 500 & 10 & 0.01 \\
\hline II & $\begin{array}{c}\text { Open area, Farmland, Rural Area } \\
\text { Scattered trees and lowrise buildings in the area }\end{array}$ & 0.16 & 600 & 10 & 0.05 \\
\hline III & $\begin{array}{c}\text { Dense trees and lowrise buildings in the area } \\
\text { Scattered high or middlerise buildings in the area } \\
\text { Gradual hills }\end{array}$ & 0.22 & 700 & 15 & 0.3 \\
\hline IV & $\begin{array}{c}\text { Dense high or middlerise building s in the area } \\
\text { Rugged hills }\end{array}$ & 0.29 & 700 & 30 & 1.0 \\
\hline
\end{tabular}

$$
\begin{aligned}
& K_{Z}=1.925\left(\frac{Z}{Z_{G}}\right)^{a}, Z \geq Z_{b} \\
& K_{Z}=1.925\left(\frac{Z}{Z_{G}}\right)^{a}, Z<Z_{b}
\end{aligned}
$$

\subsection{Determining model of extreme distribution}

The distribution model of annual maximum wind speed, like the standards posed by the Highway Bridge Design Code and Korean Building Code-Structural [15], is uniformly applied in each region under the assumption that Gumbel's distribution is the most suitable distribution type for wind speed in Korea. Gumbel's distribution function is given in Eq. (4).

$$
F(V)=\exp \left[-e^{-a(V-b)}\right]
$$

Here, $\mathrm{F}(\mathrm{v})$ is the nonexceedance probability and $\mathrm{V}$ is the annual maximum wind speed $(\mathrm{m} / \mathrm{s})$; $\mathrm{a}$ (scale parameter) and $\mathrm{b}$ (location parameter) are integers used as parameters of distribution type (characteristic value).

Assuming that the distribution of annual maximum wind speed is similar to Gumbel's distribution type, the expected value of the return period $\mathrm{T}$ and the cumulative distribution function $\mathrm{F}(\mathrm{V})$ from $\mathrm{Eq}$. (4) have the following relationship. Once Eq. (5) is inserted in Eq. (4), the return-period wind speed V(T) can be expressed as following Eq. (6).

$$
\begin{aligned}
& F(V)=1-\left(\frac{1}{T}\right) \\
& V(T)=-\frac{1}{a} \operatorname{In}\left[\operatorname{In}\left(\frac{T}{T-1}\right)\right]+b
\end{aligned}
$$

\subsection{Parameter estimation}

Typical ways to estimate parameters are the method of moment, the maximum likelihood estimation, and the least-squares method. In this study, two widely-used methods (the method of moment and the least-squares method) are applied for estimation; the maximum likelihood method is excluded because it is not very suitable if there is a small number of a sample. Parameters a and $\mathrm{b}$ can be obtained by the method of moment using the following Eqs. (7)-(8).

$$
\begin{aligned}
& a=\frac{1}{0.78 \times \sigma} \\
& b=\bar{V}-0.45 \sigma
\end{aligned}
$$

where $\bar{V}$ is the average of annual maximum wind speed and $\sigma$ is the standard deviation.

The least-squares method selects sample regression straight line with the form $y=a x+b$, which minimizes the sum of squares of errors from wind speed data; then, parameters $a$ and $b$ can be solved for as displayed in Eqs. (9)-(10). 


$$
\begin{aligned}
& a=\frac{\sum_{i=1}^{n} x y-\frac{\sum_{i=1}^{n} x \sum_{i=1}^{n} y}{n}}{\sum_{i=1}^{n} x^{2}-\frac{\left(\sum_{i=1}^{n} x\right)}{n}} \\
& b=\frac{1}{n} \sum_{i=1}^{n} y-\frac{a}{n} \sum_{i=1}^{n} x
\end{aligned}
$$

\subsection{Suitability estimation}

To estimate the suitability of the presumption equation from the extreme value distribution and the parameters, the Hazen Plot method shown in Eq. (11), considered to be the most suitable for the Gumbel distribution is applied in this study [9].

$$
F\left(V_{i}\right)=1-\frac{2 i-1}{2 n}
$$

where $F\left(V_{i}\right)$ is the nonexceedance probability, $n$ is the number of samples, and $i$ is the rank that annual maximum wind speed is sorted in descending order. Suitability for the observation that is obtained using the Hazen Plot method and the wind speed value calculated using the cumulative distribution function obtained from the least-squares method and the method of the moment is evaluated using the root mean square (RMS) error, Eq. (12), one of the ways to verify probability models.

$$
E=\frac{\sqrt{\frac{1}{n} \sum_{i=0}^{n}\left(V_{i}-v_{i}\right)^{2}}}{\frac{1}{n_{i}} \sum_{i=0}^{n} v_{i}}
$$

\section{Estimation of Expected Wind Speed and Review}

\subsection{Estimation of regional expected wind speed}

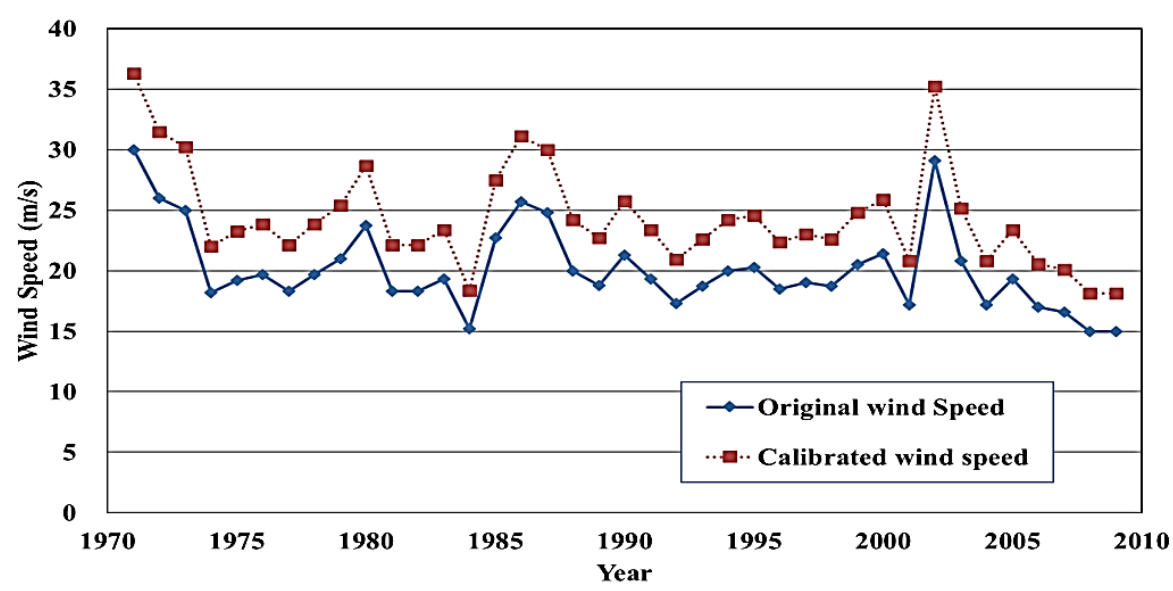

Fig. 2 Wind speed of revised surface roughness (Mokpo)

The calculation process of the expected value is performed with the Mokpo area in Korea as an example. For the homogeneity of observed data, Eqs. (2)-(3) are applied as shown in Fig. 2 and the wind speed at $10 \mathrm{~m}$ above ground and the surface roughness classification $\Pi$ are corrected through the process of Step 1 to 3 in 2.1. The revision results showed a difference of $5 \mathrm{~m} / \mathrm{s}$ wind speed; with this, the importance of revising the surface roughness and observation data modifications can be seen. 
The next process is the method of moment applied to Eqs. (7)-(8); the least-squares method is also applied to Eqs. (9)-(10), respectively. Finally, the parameters are estimated and the characteristic values of distribution types are calculated.

Assuming that the distribution of annual maximum wind speed is in accordance with the Gumbel distribution, the expected wind speeds $\mathrm{V}(\mathrm{T})$ of return period T can be shown as Eq. (6) and the expected value of the return period for the maximum wind speed in the southern and western coasts presented by the Highway Bridge Design Code is arranged in Table 3.

Table 3 Wind speeds for a return period of annual maximum wind speed and the wind speed correction on th e sea

\begin{tabular}{|c|c|c|c|c|c|c|c|c|c|c|c|}
\hline \multirow[b]{2}{*}{ Place name } & \multirow[b]{2}{*}{$\begin{array}{c}\text { Estimation } \\
\text { Method }\end{array}$} & \multirow[b]{2}{*}{$N$} & \multirow[b]{2}{*}{$\bar{v}(m / s)$} & \multirow[b]{2}{*}{$\sigma(m / s)$} & \multirow[b]{2}{*}{$\alpha(m / s)$} & \multirow[b]{2}{*}{$b(\mathrm{~m} / \mathrm{s})$} & \multirow[b]{2}{*}{$\begin{array}{l}\mathrm{RMS} \\
\mathrm{E}(\%)\end{array}$} & \multicolumn{4}{|c|}{ The statistics of the last 40 years $(1970 \sim 2009)(\mathrm{m} / \mathrm{s})$} \\
\hline & & & & & & & & $\begin{array}{c}\text { General } \\
\text { Bridge }\left(\mathrm{V}_{100}\right)\end{array}$ & $\begin{array}{c}\text { Long-span } \\
\text { Bridge }\left(V_{200}\right)\end{array}$ & $\begin{array}{c}\mathrm{V}_{200} \\
(0.005 \mathrm{~m})\end{array}$ & $\begin{array}{l}\text { Long-span } \\
\text { Bridge in } \\
\text { the } \\
\text { sea }\left(\mathrm{V}_{\text {water }}\right) \\
\end{array}$ \\
\hline \multirow[b]{2}{*}{ Seosan } & $\begin{array}{l}\text { Moment } \\
\text { Method }\end{array}$ & 39 & \multirow[b]{2}{*}{18.29} & \multirow[b]{2}{*}{2.96} & 0.43 & 16.96 & 3.3 & 27.57 & 29.18 & 35.98 & 42.33 \\
\hline & $\begin{array}{c}\text { Least } \\
\text { Square } \\
\text { Method }\end{array}$ & 39 & & & 0.4 & 16.93 & 1.5 & 28.52 & 30.28 & 37.34 & 43.92 \\
\hline \multirow[b]{2}{*}{ Incheon } & $\begin{array}{l}\text { Moment } \\
\text { Method }\end{array}$ & 39 & \multirow[b]{2}{*}{22.18} & \multirow[b]{2}{*}{3.99} & 0.32 & 20.38 & 2.1 & 28.90 & 30.71 & 37.86 & 44.22 \\
\hline & $\begin{array}{c}\text { Least } \\
\text { Square } \\
\text { Method }\end{array}$ & 39 & & & 0.29 & 20.31 & 1.5 & 30.11 & 32.10 & 39.58 & 46.22 \\
\hline \multirow[b]{2}{*}{ Gunsan } & $\begin{array}{l}\text { Moment } \\
\text { Method }\end{array}$ & 39 & \multirow[b]{2}{*}{21.89} & \multirow[b]{2}{*}{4.3} & 0.3 & 19.96 & 3.6 & 35.38 & 37.71 & 46.50 & 54.7 \\
\hline & $\begin{array}{c}\text { Least } \\
\text { Square } \\
\text { Method }\end{array}$ & 39 & & & 0.27 & 19.9 & 1.5 & 36.71 & 39.25 & 48.39 & 56.93 \\
\hline \multirow[b]{2}{*}{ Yeosu } & $\begin{array}{l}\text { Moment } \\
\text { Method }\end{array}$ & 39 & \multirow[b]{2}{*}{26.54} & \multirow[b]{2}{*}{5.65} & 0.23 & 24 & 2.7 & 37.33 & 40.45 & 49.87 & 58.25 \\
\hline & $\begin{array}{c}\text { Least } \\
\text { Square } \\
\text { Method } \\
\end{array}$ & 39 & & & 0.21 & 23.91 & 1.5 & 40.72 & 43.79 & 53.99 & 63.05 \\
\hline \multirow[b]{2}{*}{ Tong-yeong } & $\begin{array}{l}\text { Moment } \\
\text { Method }\end{array}$ & 39 & \multirow[b]{2}{*}{24.21} & \multirow[b]{2}{*}{5.07} & 0.25 & 21.93 & 3 & 35.92 & 38.38 & 47.32 & 55.67 \\
\hline & $\begin{array}{c}\text { Least } \\
\text { Square } \\
\text { Method }\end{array}$ & 39 & & & 0.23 & 21.86 & 1.5 & 37.409 & 40.11 & 49.46 & 58.19 \\
\hline \multirow[b]{2}{*}{ Jeju } & $\begin{array}{l}\text { Moment } \\
\text { Method }\end{array}$ & 39 & \multirow[b]{2}{*}{19.36} & \multirow[b]{2}{*}{4.4} & 0.29 & 17.38 & 0.9 & 33.16 & 35.55 & 43.83 & 51.57 \\
\hline & $\begin{array}{c}\text { Least } \\
\text { Square } \\
\text { Method }\end{array}$ & 39 & & & 0.29 & 17.47 & 0.5 & 33.5 & 35.93 & 44.30 & 52.12 \\
\hline \multirow[b]{2}{*}{ Mokpo } & $\begin{array}{l}\text { Moment } \\
\text { Method }\end{array}$ & 39 & \multirow[b]{2}{*}{24.38} & \multirow[b]{2}{*}{4.23} & 0.3 & 22.48 & 4.2 & 35.85 & 38.04 & 46.90 & 54.78 \\
\hline & $\begin{array}{c}\text { Least } \\
\text { Square } \\
\text { Method }\end{array}$ & 39 & & & 0.28 & 22.4 & 1.5 & 37.15 & 39.53 & 48.74 & 56.92 \\
\hline \multirow[b]{2}{*}{ Ulsan } & $\begin{array}{l}\text { Moment } \\
\text { Method }\end{array}$ & 39 & \multirow[b]{2}{*}{16.24} & & 0.36 & 14.64 & 2.7 & 27.39 & 29.32 & 36.15 & 42.53 \\
\hline & $\begin{array}{c}\text { Least } \\
\text { Square } \\
\text { Method }\end{array}$ & 39 & & 3.55 & 0.33 & 15.59 & 4.1 & 29.6 & 31.71 & 39.10 & 46.0 \\
\hline & $\begin{array}{l}\text { Moment } \\
\text { Method }\end{array}$ & 39 & & & 0.31 & 15.5 & 3.2 & 29.6 & 31.99 & 39.44 & 46.4 \\
\hline Seo-gwipo & $\begin{array}{c}\text { Least } \\
\text { Square } \\
\text { Method }\end{array}$ & 39 & 16.9 & 4.1 & 0.28 & 14.99 & 1.4 & 29.77 & 33.6 & 41.43 & 48.74 \\
\hline & $\begin{array}{l}\text { Moment } \\
\text { Method }\end{array}$ & 39 & & & 0.29 & 24.35 & 3.4 & 35.88 & 38.01 & 46.87 & 54.73 \\
\hline Busan & $\begin{array}{c}\text { Least } \\
\text { Square } \\
\text { Method }\end{array}$ & 39 & 26.32 & 4.38 & 0.27 & 24.3 & 1.5 & 37.11 & 39.44 & 48.63 & 56.79 \\
\hline
\end{tabular}




\subsection{Analysis and judgement of suitability}

The expected wind speed of return period-obtained using the least-squares method and the method of moment-and the observations graphed using the RMS error method are reviewed for stability; then, a reliable estimation method was determined. Fig. 3 is a result of the fit test about Mokpo area. The rate of error is $4.2 \%$ for Gumbel's method of moment and $1.5 \%$ for the least-squares method.

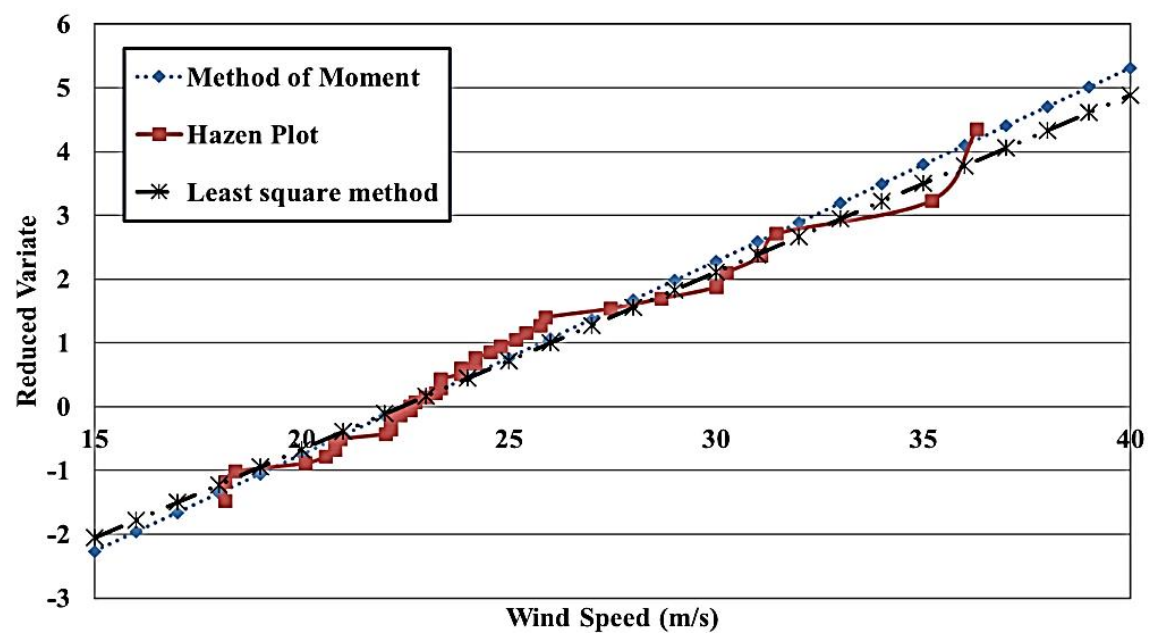

Fig. 3 Comparison between Hazen Plot and compatibility of parameter estimation (Mokpo)

By this method, results of suitability (shown in Table 3) in 10 areas of the Southern and Western coast show that the estimation of return period wind speed results in less rate of error with the least-squares method than Gumbel's method of the moment in all regions except for Ulsan in Korea. The main reason that the rate of error is decreased by the least-squares method compared to Gumbel's method of the moment in Southern and Western coast is that the wind speed is changed because of the weather change and a recent huge typhoon. Therefore, when estimating the current design wind speed, it is more suitable to use the least-squares method than Gumbel's moment method.

\subsection{Revision of marine wind speed}

For marine long-span bridges built on the coastlines, the extreme wind speed is caused by wind from the seas. Basic wind speed should be modified to represent marine wind speed because the basic wind speed is estimated by measuring from the ground. In theory, the surface wind speed is $0 \mathrm{~m} / \mathrm{s}$ on the ground because of adhesion conditions. However, for the water surface, marine wind speed is faster than the ground wind speed at the same roughness length because the wind speed is getting the same with moving speed of surface by adhesion conditions.

After looking into previous researches and literatures, we saw that the HUR 7-120 [16] report used the value of 0.78 for the examining coefficient that reduces wind speed from marine wind speed to land wind speed when marine wind speed is in excess of 37m/s. The following Eq. (13) was proposed in the case of Simiu et al. [17].

$$
\frac{V_{\text {land }}}{V_{\text {water }}}=\frac{1}{0.2 p \ln \frac{10}{z_{0}}}
$$

where $\mathrm{V}_{\text {land }}$ is the land wind speed, $\mathrm{V}_{\text {water }}$ is the marine wind speed, $\rho$ is the reduction factor, and $\mathrm{Z}_{0}$ is the roughness length. Because Eq. (13) assumes that the gradient wind is a geostrophic wind, Eq. (13) may be inaccurate under extreme conditions in the presence of strong winds caused by a typhoon.

To make up for this uncertainty, Batts \& Simiu [12] estimated the coefficient shown in Eq. (14) about the wind which occurs at $10 \mathrm{~m}$ above the ground and has roughness length $Z_{0}=0.005 \mathrm{~m}$ when hurricanes go offshore. 


$$
\frac{V_{\text {land }\left(z_{0}=0.005\right)}}{V_{\text {water }}}=0.85
$$

Since the return period wind speed estimated by the extreme analysis method is $10 \mathrm{~m}$ above the ground which has the surface roughness classification $\Pi\left(\mathrm{Z}_{0}=0.05 \mathrm{~m}\right)$, the log wind profile Eq. (15) is used to obtain the wind speed in $\mathrm{Z}_{0}=0.005 \mathrm{~m}$.

$$
V(z)=\frac{u^{*}}{k} \ln \left(\frac{z}{z_{0}}\right)
$$

were $\mathrm{k}$ is the Karman constant $(\fallingdotseq 0.4), \mathrm{u}$ is the shear velocity by the surface, and $\mathrm{Z}_{0}$ is the roughness length. The friction velocity ratio of the two cases is required in order to estimate the wind speed using log wind profiles. Eq. (16) is applied on the basis of the study by Simiu and Scanlan [18].

$$
\frac{u_{\left(z_{0}=0.005\right)}^{*}}{u_{\left(z_{01}=0.05\right)}^{*}}=\left(\frac{z_{0}}{z_{0}}\right)^{0.0706}=0.85
$$

The revised wind speeds in 10 areas of the southern and western coasts using Eqs. (14)-(16) are presented in Table 3. As a result of the application, the wind speeds with the wind correction factor are approximately 1.45 times faster than land wind speed.

\subsection{Analysis of results}

Using the same process as above, the expected wind speeds of 200-year return period for a long-span bridge and the revised marine wind speeds are calculated using experimental data and presented in Table 3 . The basic wind speed of the current bridge design standards is elevated by considering the safety factor (15-30\%) based on the previous estimation method [19]. But when the meteorological data on global warming is taken into account, there are irregularities corresponding to a

\begin{tabular}{|c|c|c|c|c|}
\hline \multirow{2}{*}{ Place name } & \multirow{2}{*}{$\begin{array}{l}\text { Bridge Design } \\
\text { Criteria (2005) }\end{array}$} & \multirow{2}{*}{ Estimation Method } & \multicolumn{2}{|r|}{ General Bridge } \\
\hline & & & $V_{100}$ & A percentage change $(\%)$ \\
\hline \multirow{2}{*}{ Seosan } & \multirow{2}{*}{35} & Moment Method & 27.57 & 21.23 \\
\hline & & Least Square Method & 28.52 & 18.51 \\
\hline \multirow{2}{*}{ Incheon } & \multirow{2}{*}{35} & Moment Method & 34.72 & 0.80 \\
\hline & & Least Square Method & 36.17 & -3.34 \\
\hline \multirow{2}{*}{ Gunsan } & \multirow{2}{*}{40} & Moment Method & 35.38 & 11.55 \\
\hline & & Least Square Method & 36.71 & 8.22 \\
\hline \multirow{2}{*}{ Yeosu } & \multirow{2}{*}{40} & Moment Method & 44.26 & -10.65 \\
\hline & & Least Square Method & 46.19 & -15.48 \\
\hline \multirow{2}{*}{ Tong-yeong } & \multirow{2}{*}{40} & Moment Method & 40.12 & -0.30 \\
\hline & & Least Square Method & 41.79 & -4.48 \\
\hline \multirow{2}{*}{ Jeju } & \multirow{2}{*}{45} & Moment Method & 33.16 & 26.31 \\
\hline & & Least Square Method & 33.5 & 25.56 \\
\hline \multirow{2}{*}{ Mokpo } & \multirow{2}{*}{45} & Moment Method & 37.65 & 16.33 \\
\hline & & Least Square Method & 38.96 & 13.42 \\
\hline \multirow{2}{*}{ Ulsan } & \multirow{2}{*}{45} & Moment Method & 27.39 & 39.13 \\
\hline & & Least Square Method & 29.6 & 34.22 \\
\hline \multirow{2}{*}{ Seogwipo } & \multirow{2}{*}{45} & Moment Method & 29.77 & 51.15 \\
\hline & & Least Square Method & 31.16 & 44 \\
\hline \multirow{2}{*}{ Busan } & \multirow{2}{*}{40} & Moment Method & 40.08 & -0.20 \\
\hline & & Least Square Method & 41.52 & -3.80 \\
\hline
\end{tabular}
-15.48 to $51.15 \%$ difference with the Highway Bridge Design Code, as shown in Table 4.

Table 4 Comparison between Highway Bridge Design Code and wind speeds of 100-year return period 
Therefore, the basic wind speeds presented in the previous design standards need significant revisions. For similar reasons, the expected basic wind speeds of 200-year return period and marine wind speed presented in the Design Guidelines for Steel Cable-Supported Bridge also need to be revised; the basic wind speed of marine regions should also be continuously researched. As shown in Table 3, the expected basic wind speeds of 200-year return period for a long-span bridge are compared using both the moment method and the least-squares method; although both methods are suitable (within 5\% error), the least-squares method is better because the rate of error is less than $1.5 \%$ for all regions except for Ulsan.

\section{Conclusion}

In this study, the design basic wind speed of the long-span bridge proposed by the Design Guidelines for Steel Cable-Supported Bridge is analyzed. Typhoons frequently occur in the southern and western coasts due to a rapidly changing climate. Thus, based on the most recent data, the moment method and the least-squares method are used to estimate the design basic wind speed that is suitable for a long-span bridge, and the RMS error method is also used to evaluate suitability. Based on these results, the following conclusions are obtained.

1. In the results of estimating the expected wind speeds of a 100 year return period with the latest data, if a safety factor of -15.24 to $39.13 \%$ was accounted for in the Bridge Design Standard, it could have occurred as a result of the increasing intensity and frequency of winds caused by the changing climate. Therefore, the expected wind speeds of 100-year return period need to be re-estimated with continued research to reflect the appropriate safety factor.

2. The basic wind speeds in the southern and western coasts are compared using both the moment method and the least-squares method; as a result, both methods are suitable with a rate of error that is less than $5 \%$. In particular, the least-squares method proves to be better than the moment method because the least-squares method has a rate of error that is less than $1.5 \%$ in all regions except for Ulsan.

3. When estimating the expected wind speed for long-span bridges in coastal area in the paths of typhoons, the revised value is 1.45 times the previous value when considering marine wind speed under extreme conditions.

4. For the southern and western coastal regions of Korea, conservative wind design is needed because of uncertainty in basic wind speed estimation and safety when facing large-scale typhoons. The alternative applied to marine wind speed revision for the basic wind speeds of 200-year return period is proposed.

The data from the weather center is thoroughly analyzed and stochastically estimated to propose the expected wind speed of the return period (100, 200 years) and long-span bridge at sea. Therefore, based on the reliable data regarding the rise in sea temperature and intensity and frequency of marine wind speed, studies for estimating the design basic wind speed of long-span bridges suitable for extreme marine wind near the southern and western coasts should be continued. Hence, the rapidly changing environment calls for the need to make safety reviews of long-span bridges in use to reflect the results of this research.

\section{Conflicts of Interest}

The authors declare no conflict of interest.

\section{References}

[1] Korean Highway Bridge Design Code Limit state design, Ministry of Land, Infrastructure and Transport, Korea, 2014.

[2] Design Guidelines for Steel Cable-Supported Bridge, Korean Society of Civil Engineers, 2006.

[3] R. Rahnavard, M. Taghikhajeh, A. Hassanipour, and N. Siahpolo, "Parametric study of seismic performance of steel bridges pier rehabilitated with composite connection," Journal of structure and construction engineering, vol. 10, pp. 98-113, 2017. 
[4] D. W. Kim and Y. C. Ha, "Estimation of wind speeds for return period in major cities reflecting the recent meteorological data," Journal of the Wind Engineering Institute of Korea, vol. 8, pp. 147-154, 2004.

[5] V. L. Brano, A. Orioli, G. Ciulla and S. Culotta, "Quality of wind speed fitting distributions for the urban area of Palermo, Italy,” Renewable Energy, vol. 36, pp. 1026-1039, March 2011.

[6] O. A. Jaramillo and M. A. Borja, "Wind speed analysis in La Ventosa, Mexico: a bimodal probability distribution case," Renewable Energy, vol. 29, pp. 1613-1630, August 2004.

[7] T. B. M. J. Ouarda, C. Charron, J. Y. Shin, P. R. Marpu, A. H. Al-Mandoos, M. H. Al-Tamimi, H. Ghedira and T. N. Al Hosary, "Probability distributions of wind speed in the UAE," Energy Conversion and Management, vol. 93, pp. 414-434, 2015.

[8] J. Zhou, E. Erdem, G. Li and J. Shi, "Comprehensive evaluation of wind seed distribution models: A case study for North Dakota sites," Energy Conversion and Management, vol. 51, pp. 1449-1458, 2010.

[9] O. Alavi, A. Sedaghat, and A. Mostafaeipour, "Sensitivity analysis of different wind speed distribution models with actual and truncated wind data: A case study for Kerman, Iran," Energy Conversion and Management, vol. 20, pp. 51-61, 2016.

[10] E. K. Akpinar, S. Akpinar, and N. Balpetek, "Statistical analysis of wind speed distribution of Turkey as regional," Journal of Engineering Technology and Applied Sciences, vol. 3, pp. 35-55, 2018.

[11] X. Qing, "Statistical analysis of wind energy characteristics in Santiago island, Cape Verde," Renewable Energy, vol. 115, pp. 448-461, 2018.

[12] D. Cho, H. Jeong, and J. Choi, "A study of the bolt connection system for a concrete barrier of a modular bridge," International Journal of Engineering and Technolgy Innovation, vol. 8, no. 2, pp. 107-117, April 2018.

[13] M. E. Batts, L. R. Russell, and E. Simiu, "Hurricane wind speeds in the United States," ASCE Journal of Structural Division, vol. 106, pp. 2001-2016, 1980.

[14] Annual Weather Report, Korean Meteorological Administration, 1971-2017.

[15] Korean Building Code-Structural (KBC2005), Architectural Institute of Korea, Chapter 3, 2005.

[16] Revised Standard Project Hurricane Criteria for the Atlantic and Gulf Coast, Memorandum HUR 7-120, Hydrometeorological Branch Office of Hydrology, NOAA, National Weather Service, USA, 1972.

[17] E. Simiu, J. Bietry, and J. J. Filliben, "Sampling errors in the estimation of extreme wind," Journal of the Structural Division, ASCE, vol. 104, pp. 491-501, 1978.

[18] E. Simiu and R. H. Scalan, Wind effects on structures: fundamentals and applications to design, 3rd ed. John Wiley and Sons, 1996.

[19] S. S. Park, "A study on wind loads for bridges," MA. dissertation, Dept. Civil Eng., Kyunghee Univ., Korea, 2004.

Copyright $\odot$ by the authors. Licensee TAETI, Taiwan. This article is an open access article distributed under the terms and conditions of the Creative Commons Attribution (CC BY-NC) license (https://creativecommons.org/licenses/by-nc/4.0/). 